Special issue: Radical Periodicals

Article

\section{Black power print}

\author{
E. James West
}

Northumbria University, UK; ejwestuk@gmail.com

How to Cite: West, E.J. 'Black power print.' Radical Americas 3, 1 (2018): 14.

DOI: https://doi.org/10.14324/111.444.ra.2018.v3.1.014.

Acceptance date: 1 August 2018; Publication date: 30 November 2018

\section{Peer review:}

This article has been peer reviewed through the journal's standard double blind peer-review, where both the reviewers and authors are anonymised during review.

\section{Copyright:}

(C) 2018, E. James West. This is an open access article distributed under the terms of the Creative Commons Attribution License (CC BY) 4.0 https://creativecommons.org/licenses/by/4.0/, which permits unrestricted use, distribution and reproduction in any medium, provided the original author and source are credited $\bullet$ DOI: https://doi.org/10.14324/111.444.ra.2018.v3.1.014.

\section{Open access:}

Radical Americas is a peer-reviewed open access journal.

\begin{abstract}
This photographic essay focuses on the cover art of a wave of black radical periodicals which emerged in the United States during the 1960s to shed light on the intersections between Black Power, graphic design and black print culture. By examining the graphic design and artwork employed by 'little black magazines' such as Liberator, Soulbook and Black America, we can see the origins of a Black Power visual aesthetic which was most memorably rendered through the work of Emory Douglas and the Black Panther community newspaper during the late 1960s and early 1970s. In turn, I argue that such cover art can be understood as just one example of the visual intersections which emerged between black radical activism and black print culture in the United States during the years following World War II.
\end{abstract}

Keywords: Black Power; African American; Graphic Design; Periodicals; 1960s; Black Panther; Soulbook; Black America; Umbra 
Visitors to the recent exhibit 'Soul of A Nation: Art in the Age of Black Power' at the Tate Modern in London may have been surprised to find copies of the Black Panther newspaper jostling for attention alongside the work of pioneering black artists such as Romare Bearden and Elizabeth Catlett. ${ }^{1}$ In both scholarly and popular analyses of the Black Arts Movement - the artistic 'wing' of the Black Power Movement which flowered during the 1960s and early 1970s - the graphic design and artwork of black periodicals has tended to slip into the cracks between a literary focus on writers such as Hoyt Fuller, Nikki Giovanni and Sonia Sanchez and the celebration of more 'recognisable' forms of artistic production such as painting or portraiture. ${ }^{2}$ Indeed, with the notable exception of Emory Douglas, whose graphic artwork for the Black Panther has received renewed attention in recent years, Black Power's visual influence on black print culture has remained curiously understudied in the literature. ${ }^{3}$ This is striking, given both the tremendous surge in Black Power scholarship over the past two decades and the ways in which the cover design and graphic art of black radical periodicals embodied the myriad demands and concerns of Black Power activists. This photographic essay focuses on the cover art of a wave of black radical periodicals which emerged in the United States during the 1960s to shed light on the intersections between Black Power, graphic design and black print culture.

\section{Black power/black radical print}

In the 15 years since Peniel Joseph first called attention to the emergence of 'Black Power Studies', a diverse range of scholarship has helped to recover, re-periodise and redefine an often maligned and misunderstood era. ${ }^{4}$ Rejecting clichéd representations of Black Power as a counterproductive offshoot to the 'mainstream' black freedom struggle, researchers have come to understand the concept as a complex and multivalent force that was rooted in, but not limited to, the appeal of black nationalism and a desire for self-determination and which often 'affirmed black people in ways the civil rights movement did not'. Yet, despite such progress, there is much work which remains to be done. Prominent individuals and organisations such as Stokely Carmichael and the Black Panther Party continue to consume much of the field's oxygen, while Joseph's formulation of 'Black Power Studies' has often been equated with merely histories of Black Power. ${ }^{6}$ To develop the field further, we must pursue a truly interdisciplinary approach to Black Power; one which interrogates the movement's influence over and intersections with broader institutions and practices, such as the black church, black politics and black print culture. ${ }^{7}$

If Black Power has been a tricky term to define, we must also recognise the contested history and terminology of 'black print culture' as well as the changing nature and definition of black radical print. ${ }^{8}$ In many ways, black print culture has always been radical. Throughout American history, black editors and authors have militantly agitated for racial equality - from the abolitionism of antebellum black newspapers, to the campaigns of progressive era anti-lynching journalism, the popular front politics of black literary magazines during the interwar period and the rise of black-led anticolonial periodicals such as Paul Robeson's Freedom during the early Cold War. ${ }^{9}$ At the same time, each new wave has led to a reassessment of black radicalism and its relationship to print culture. How might readers assess the relative merits of magazines such as the Messenger, developed by black labour activist A. Philip Randolph and described by the US Attorney General as 'the most dangerous of all the negro publications', against newspapers such as Marcus Garvey's Negro World, a 'radical black periodical' which built grand literary and international ambitions on a framework of conservative business acumen and entrepreneurship? ${ }^{10}$ How might we assess the impact of organs such as The Crisis, a militant voice for racial justice during the first decades of the twentieth century, but a periodical later pilloried for its integrationist tendencies by 'revolutionary' black magazines of the 1960s? ${ }^{11}$

In seeking to address such questions, scholars have expanded their analysis from a specific focus on literary and editorial politics to consider the importance of things such as circulation, readership and design. ${ }^{12}$ Much of this work has centred on rich cultural and political flowerings of the Harlem Renaissance and New Negro Movement during the first decades of the twentieth century. For black periodicals such as The Crisis and Opportunity, artwork and graphic design became a vital tool for reinforcing underlying editorial beliefs and disseminating a clear vision of black modernity. In turn, aspiring black artists of the period found a welcome avenue for their work, as well as a steady income, within the realm of black 
print culture. Perhaps, the most notable of these figures was Aaron Douglas, who subsidised his artistic passions through a job in the mail room of The Crisis, before rising to a position as its art editor. Clare Corbould has argued that the work of Douglas and other black artists of the era 'gave visual form to the sentiments expressed' on the pages of black periodicals. ${ }^{13}$ Several decades later, changes in the aesthetics of black print culture both reflected and helped to give form to the emergence of Black Power.

I do not mean to suggest that a distinctly 'new' form of black radical print culture emerged during this period, although we can certainly point to the rise of 'revolutionary little [black] magazines', as well as 'Black Power literature' such as Sam Greenlee's The Spook Who Sat By The Door, as evidence for Black Power's influence over African American cultures of print. ${ }^{14}$ Rather, I posit that Black Power as an intellectual and artistic force helped to foster important intersections between black radical activism and black radical print culture. In turn, Black Power intersected with, influenced and was influenced by broader currents in national and international politics and print culture. Revolutionary black journals and literature overlapped with the 'little magazines' and journals of the New Left and New Right, as well as with more moderate and consumer-oriented black periodicals, to help create a literary and visual language of Black Power. This can be seen in everything from the bold lines, high contrast and slab-serif text cover of Stokely Carmichael and Charles V. Hamilton's seminal 1967 work Black Power: The Politics of Liberation in America, which became a visual embodiment of the militant rhetoric and radical chic of Black Power politics, to the production of Black Power-inspired cover art and advertising campaigns in glossy consumer magazines such as Ebony and Essence. ${ }^{15}$

There remains much to be said about both the cover art of 'Black Power books' and the willingness of more moderate print outlets to embrace the aesthetic appeal of Black Power whilst largely avoiding the radical implications of the concept. ${ }^{16}$ Unfortunately, limitations of space and copyright mean that such discussions are beyond the remit of this essay. Instead, I focus here on the cover design of nascent black periodicals such as Liberator and Umbra which emerged during the first half of the 1960s, alongside militant black journals such as Soulbook and Black America. This essay connects these lesser known outlets to the more popular cover art of Emory Douglas and the Black Panther newspaper. My description of these periodicals as 'radical' builds on the work of Christopher Tinson, Jane Rhodes and others who have situated their artistic and editorial content within a black radical tradition that 'embraces an understanding of the centrality of the social, historical, political and global construction of race and the attendant persistence of racism' in the United States. ${ }^{17}$ When taken as a whole, the graphic design and cover art of black radical periodicals presented different definitions of and strategies for Black Power, but also highlighted the complex and frequently contested ways in which Black Power influenced American print culture and graphic design during the 1960s. Despite the contrasting and at times contradictory philosophies of these outlets, their cover art helped to collectively project a powerful image of black radical activism at home and abroad.

\section{Liberator, Umbra and a black radical aesthetic}

Among the earliest 'Black Power magazines' to emerge was the Liberator, which began monthly publication out of New York in 1961. It was produced by the Liberation Committee of Africa (LCA), an embryonic black political organisation created by disillusioned architect Dan Watts, as a more formal version of an organisational newsletter titled Liberation. ${ }^{18}$ While early issues were heavily focused on African politics, reader criticisms led to more substantial coverage of the "new revolution that is taking place in the United States'. Its editors declared that black Americans could no longer sit idly by while their brothers and sisters were being jailed, beaten and murdered 'in Mississippi, Georgia, South Africa, Alabama, Florida, Angola, South Carolina, Algiers and Little Rock' ${ }^{19}$ In doing so, the Liberator sought to situate itself as a more radical voice than periodicals such as The Crisis, which were seen to have little connection to the more radical demands of younger activists and the more confrontational strategies of organisations such as CORE and the SNCC. Indeed, Tinson has positioned the Liberator as a critical outlet for black radical perspectives during the early 1960s, which 'in many ways anticipated' the rise of Black Power. ${ }^{20}$ 
Despite its ambitious editorial vision, early appearances were closer to that of a pamphlet or leaflet than a fully-fledged journal or magazine. While the LCA was able to attract luminaries such James Baldwin to its first anniversary meeting, the organisation's finances remained stretched. Data from the LCA's 1961 yearly budget shows that it brought in less than $\$ 4400$ from subscriptions and other revenue streams. ${ }^{21}$ Unsurprisingly, a strict printing budget led to low production values and basic graphic design. Mistakes, such as missing off the date of publication or price, were either left uncorrected or filled in by hand after production, while images were largely absent during its first year-and-a-half in print. To save costs, Liberator's editors eschewed a dedicated cover image, instead using a newspaper-style header with articles or announcements running directly underneath. However, as the publication grew in stature, Watts and other editors such as Lowell Beveridge began to develop a more sophisticated layout and visual appearance, starting with its cover design. In May 1962, the Liberator introduced a dedicated cover image for the first time (Figure 1) to coincide with its first anniversary.

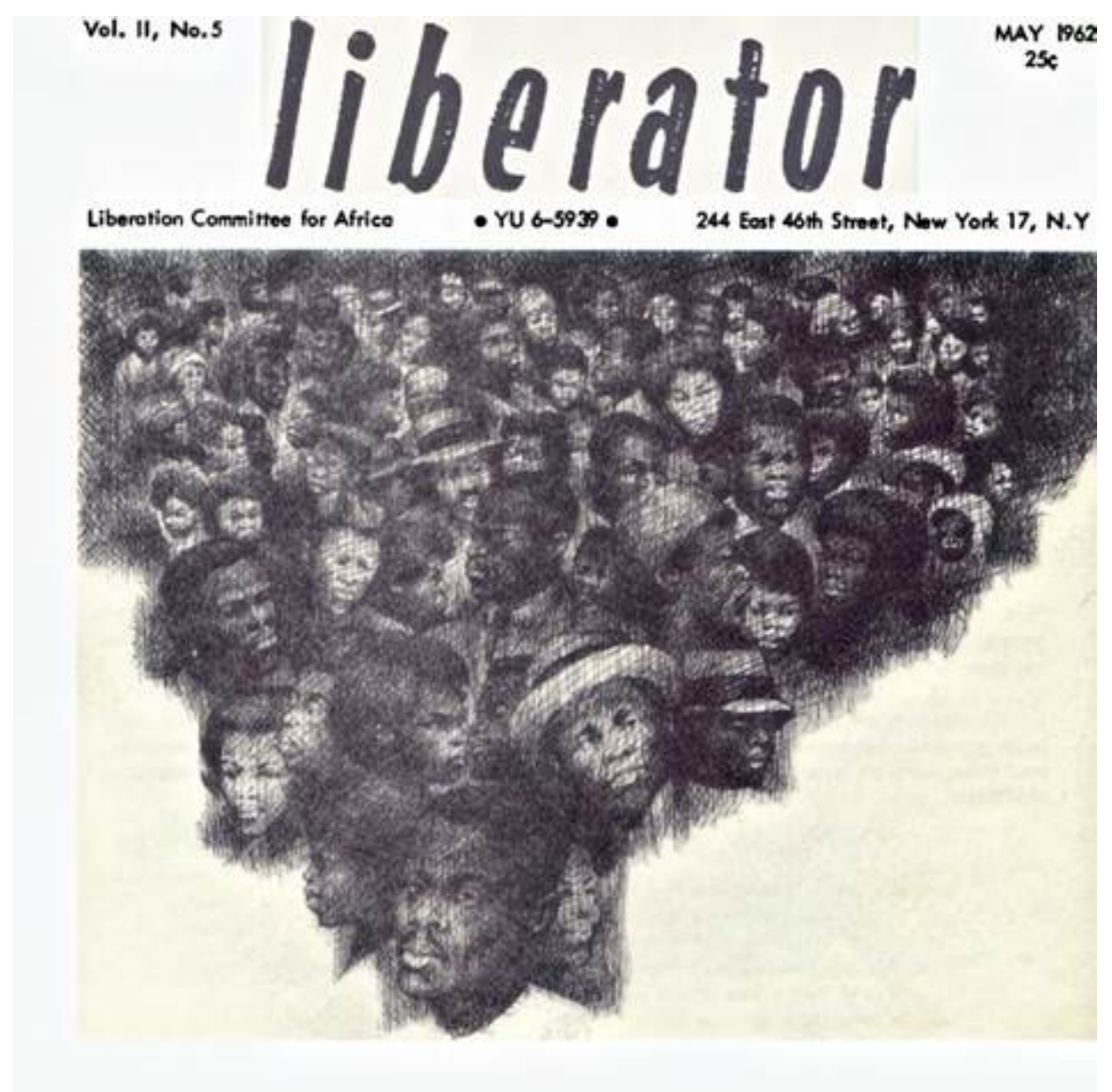

\section{first anniversary issue}

Figure 1 Cover of Liberator, May 1962. Tom Feelings.

The image on the cover was attributed to Tom Feelings, a young black artist who would go on to become a noted illustrator of children's books. Feelings had first come to prominence as the illustrator 
of the pioneering black heritage comic Tommy Traveler in the World of Negro History, which ran in the New York Age and the Chicago Defender during the late 1950s and 1960s. ${ }^{22}$ The editors of the Liberator were impressed by Feelings, describing him as a young artist with a 'fast growing reputation for drawing his own people as he sees them - with dignity and humor and, sometimes, anger' ${ }^{23}$ While the reproduction of Feelings' artwork was of relatively poor quality and in black and white to minimise the printing costs, the decision to introduce a dedicated cover page served to move the Liberator away from its origins as the LCA's newsletter and reflected its developing status as an important literary outlet for black writers. The tone of Feelings' image is also striking when compared to the covers of glossier black consumer periodicals, which utilised glamorous (and frequently light-skinned) black celebrities and models to 'mirror the happier side of negro life'. By contrast, Feelings' inaugural cover art for the Liberator was distinctly sombre. In addition, the masses of black faces depicted contrasted with the individual or portrait shots favoured by black consumer magazines, embodying an image of black proletarian struggle 'often missing from conventional portraits of black nationalism'. ${ }^{24}$

Other formatting and stylistic changes included the addition of a subtitle in October 1962, featuring a quotation from abolitionist Frederick Douglass, which warned that '[those] who would be free themselves must strike the first blow'. ${ }^{25}$ A brief description was also added to the Liberator's contents page in order to clarify its mission, informing readers that it 'is the voice of the Afro-American protest movement in the United States and the liberation movement in Africa', a statement which helped to make its emphasis on transnational and diasporic black activism more explicit. ${ }^{26}$ Two issues later, the Liberator dispensed with its lower-case header in favour of a more imposing upper-case title. In addition, the periodical moved from a simplistic segmented cover design to a multicolour format with title lettering imposed over a cover image or photograph, mimicking the design favoured by popular photo-editorial magazines such as Ebony and Life. A good example of this change in format can be seen through the periodical's July 1963 cover, which carried an image of model Rosie Nelmes. As a dark-skinned black woman with natural hair, Nelmes' portrait stood in opposition to the proclivity of black consumer magazines for lighter-skinned black cover models or entertainers, such as Lena Horne and Dorothy Dandridge.

In addition to her appearance on the cover of the Liberator, Nelmes featured prominently in a lead article titled 'Natural Hair YES, Hot Irons NO'. Declaring that straightened or relaxed hair represented a warped class consciousness and white beauty standards, the Liberator celebrated Nelmes' 'natural beauty' and argued that the embrace of 'kinky hair, full lips and a broad nose... is the beginning of a new attitude, a new era, a proud Black woman'. ${ }^{27}$ This position contrasted with the continued willingness of black consumer magazines such as Ebony to accept advertising for hair relaxants or products which promised 'lighter, brighter skin!' ${ }^{28}$ Nelmes' appearance was linked specifically to her involvement with the Harlem-based Grandassa modelling troupe which aimed to create a new beauty standard for black women by 'developing the African Look in clothing, cosmetics, and hair styling' ${ }^{29}$ More broadly, her presence on the cover of the Liberator's July 1963 issue provides us with an insight into how radical black periodicals were attempting to reshape black cultural and political norms during the early 1960s, using cover art and graphic design to help facilitate the development of a distinct Black Power 'style' which came of age during the second half of the decade. ${ }^{30}$

Umbra was another New York-based black periodical which emerged out of the city's black intellectual and cultural networks during this period. A more literary-focused publication, Umbra was affiliated with the Umbra Poets' Workshop that coalesced on the Lower East Side during the early 1960s. The Workshop was the progeny of another black nationalist literary organisation called On Guard for Freedom, which had been established by activist and educator Calvin Hicks. ${ }^{31}$ Like the Liberator, the journal had its roots in the black intellectual and literary revival which took place in Harlem during the postwar years. While Umbra only existed as a cohesive, functioning group for a couple of years, affiliates such as writer Calvin Hernton have argued that its influence upon their work was 'immeasurable and timeless'. ${ }^{32}$ Contributors such as Art Berger saw the periodical as 'the first major outlet for Negro poets since the days of Opportunity'. ${ }^{33}$ The Workshop's early development was guided by Tom Dent, who was concurrently the Publicity Director for the NAACP's Legal Defense Fund in New York. In lieu of a more permanent home, the Workshops were initially held at Dent's apartment on East 2nd Street in Manhattan. ${ }^{34}$ 
Dent envisioned Umbra as 'a device that could be a vehicle for the expression of the bitterness and the beauties of being Afro-American', and this somewhat abstract vision certainly appeared to be encapsulated through the cover of its first issue in winter 1963 (Figure 2). ${ }^{35}$ The ambiguity of the spectral face above is striking, leaving the interpretation of its expression largely open to the reader. Where some readers might see anger or even ethereal pleasure, others might envision pain or horror echoing the classical works of figures such as Edvard Munch. However, the foreword of the magazine's first issue gave a clearer indication of its orientation, informing the readers that it looked to analyse '(1) the experience of being Negro, especially in America, and (2) that quality of human awareness often termed "social consciousness"'. When read against the description provided by Umbra's editors, its inaugural cover can perhaps most readily be understood as both a cry for help and a call to arms, with its authors contending that 'we are not a self-deemed radical publication; we are as radical as society demands the truth to be'.

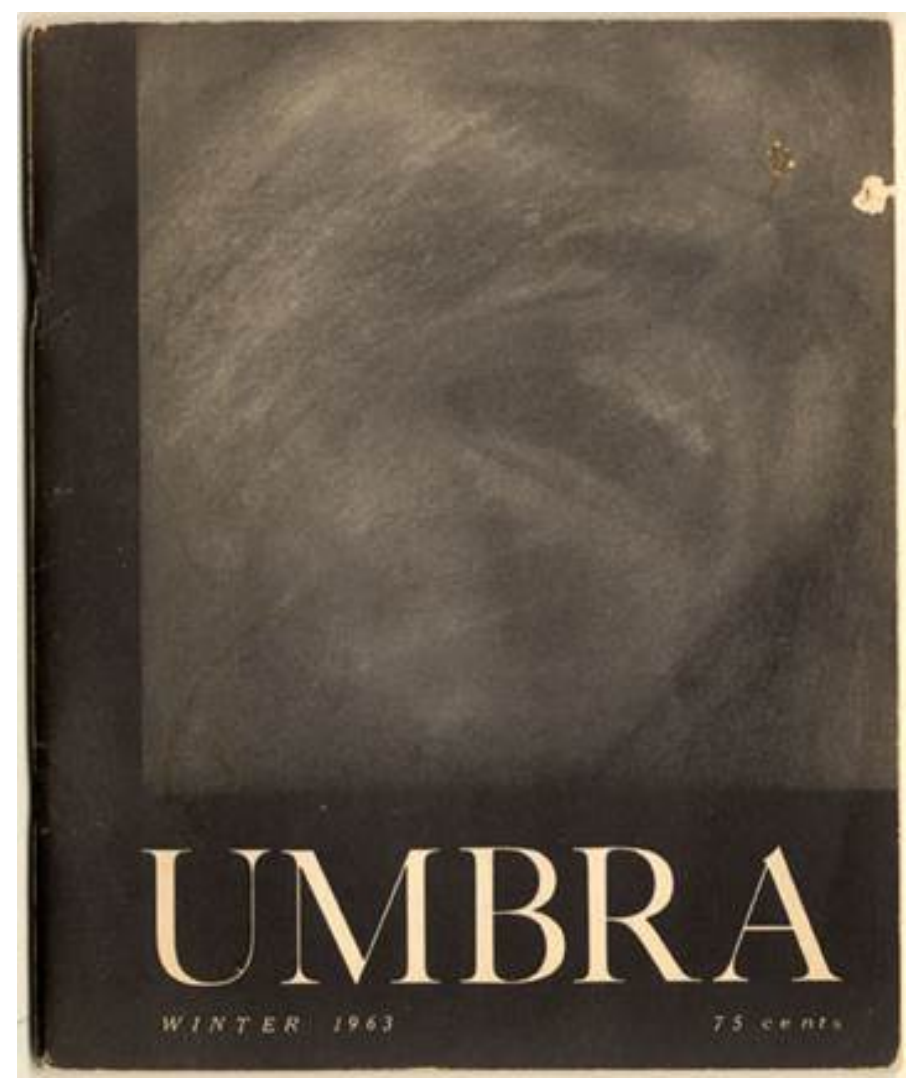

Figure 2 Cover of Umbra, (winter 1963). Unknown Artist.

The expressivity and performative dynamic at play here also points towards a key goal of Umbra; namely, a return to a recognisably African American oral tradition and mode of storytelling. The Umbra Workshops and by extension Umbra itself, sought to negotiate the 'space between the written page and the oral performance'. ${ }^{36}$ This was something which manifested itself through other forms of black cultural expression influenced by the emergence of Black Power during the 1960s, ranging from the work of Chicago-based black arts collective AFRICOBRA to the spoken word performance of early hip-hop innovators such as The Last Poets. From a more intimate perspective, the straining figure on the first cover of Umbra recalled the intense environment created in Dent's apartment for each Workshop, with dozens of writers crowded into the living room and kitchenette of Dent's Lower East Side apartment. Frequently running for five or six hours, the Workshops were 'exacting, exhausting, and challenging', with participants clashing on a wide variety of issues. In a later recollection, Hernton would declare that 'if your skin was thin, you were sure to bleed at some point or other. You would get angry, defensive, and you might depart just short of physical combat'. ${ }^{37}$ 


\section{Graphic art, manhood and black power print}

Two more black periodicals to emerge during this period were Black America and Soulbook, both of which commenced publication in 1964. Black America was a bimonthly magazine produced by the Revolutionary Action Movement (RAM), an 'anti-imperialist and Marxist black nationalist organization' that was formed in Philadelphia in 1962. ${ }^{38}$ Max Stanford, one of the group's founders, would later argue that RAM was created in reaction to the perceived 'bourgeois orientation' of many existing civil rights groups and periodicals. ${ }^{39}$ While the title of Black America reflected its initial ambitions to become a 'national public organ', it would never reach a mainstream audience. ${ }^{40}$ Nevertheless, the periodical became an important outlet for a growing community of nationalist-oriented black intellectuals, helping to expand the coverage of periodicals such as Liberator. Jeffrey Ogbar has contended that RAM was the first organisation to synthesise 'northern black nationalism, southern activism, and Third World revolutionary theory'. ${ }^{41}$ Its eventual goal, as expressed through the pages of Black America, was to forge radical transnational connections between oppressed people of colour across the globe. To this end, it sought to 'bring clarity and give direction in revolutionary struggle', to help liberate 'the African captives enslaved in the racist United States' and to push for a 'revolutionary unity' among all people of African descent. ${ }^{42}$

Stanford sketched the artwork for many Black America covers, including the image of black nationalist leader Marcus Garvey on the fall 1964 issue (Figure 3). While Stanford was a competent artist, the utilisation of his talents was largely a pragmatic one based on limited production funds - something which also influenced a preference for black-and-white images and drawings over colour photographs and artwork. However, the uniformity between cover artist and editorial content helped to create a powerful synergy between word and image. Unfortunately, this often served to reinforce gendered biases in the periodicals' discussion of black radical activism and the pursuit of black liberation. Stanford asserted that the black woman should 'see the black man as a shining prince and must be able to submit to his will and direction' and his artwork can be seen to have reified such sentiments. ${ }^{43}$ More broadly, while RAM aimed to provide black people with 'a new image of manhood and womanhood', this appeared to be rooted in a longstanding deference to male leadership and deference to a patriarchal black public sphere. ${ }^{44}$ This sentiment was reflected through the covers of Black America, the focus of its articles and the gender of its contributors. ${ }^{45}$

Such gender imbalances in cover design, content and contributors could also be seen in other new black periodicals such as Soulbook, a self-described 'revolutionary journal of Afro-America', which was first published out of Berkeley, California, during the winter of 1964. Unlike Liberator, which had welcomed interracial collaboration and whose content had been heavily influenced by white editors such as Lowell Beveridge, Soulbook pursued a more explicitly separatist agenda. ${ }^{46}$ Its editors rationalised that to ensure the full liberation of black people, the journal would be 'produced, controlled, published and edited by people who are sons and daughters of Africa' ${ }^{47}$ Carroll Holmes was the sole female editorial board member during its first year in print. Similarly, although the first cover of Soulbook featured a female African American singer, readers were usually greeted by photographs or impressionistic prints of African American men. A good example of this can be seen through the cover of its second issue, which featured a side-profile drawing of Malcolm X by editorial board member Donald Freeman (Figure 4), along with an editorial that explicitly linked Malcolm's masculinity to the ongoing struggle for black liberation.

While the covert art of periodicals such as the Liberator had provided space to critique representations of black female beauty and colourism within the black community, for many Black Power activists, the celebration of figures such as Malcolm X and Marcus Garvey became an important part of establishing a 'legitimate patrilineal lineage' for black radical activism and black masculine identities. ${ }^{48}$ Despite the undoubted centrality of black women to the formation of Black Power's ideological frameworks and central principles, the role of black women on both an individual and an institutional level was frequently marginalised within the movement. ${ }^{49}$ In turn, the content and graphic design of magazines such as Umbra, Black America and Soulbook contributed to and helped to visually codify the male-centred bias which often characterised the attitudes of Black Arts and Black Power advocates. ${ }^{50}$ Articles accompanying masculinist cover art championed black nationalist icons for showing 'US black males HOW to be MEN!... Afro-American males live only as long as they are content with not being men. Only as long as they pray and sing hymns while their women are abused, beaten and raped, their children brain washed' ${ }^{51}$ 


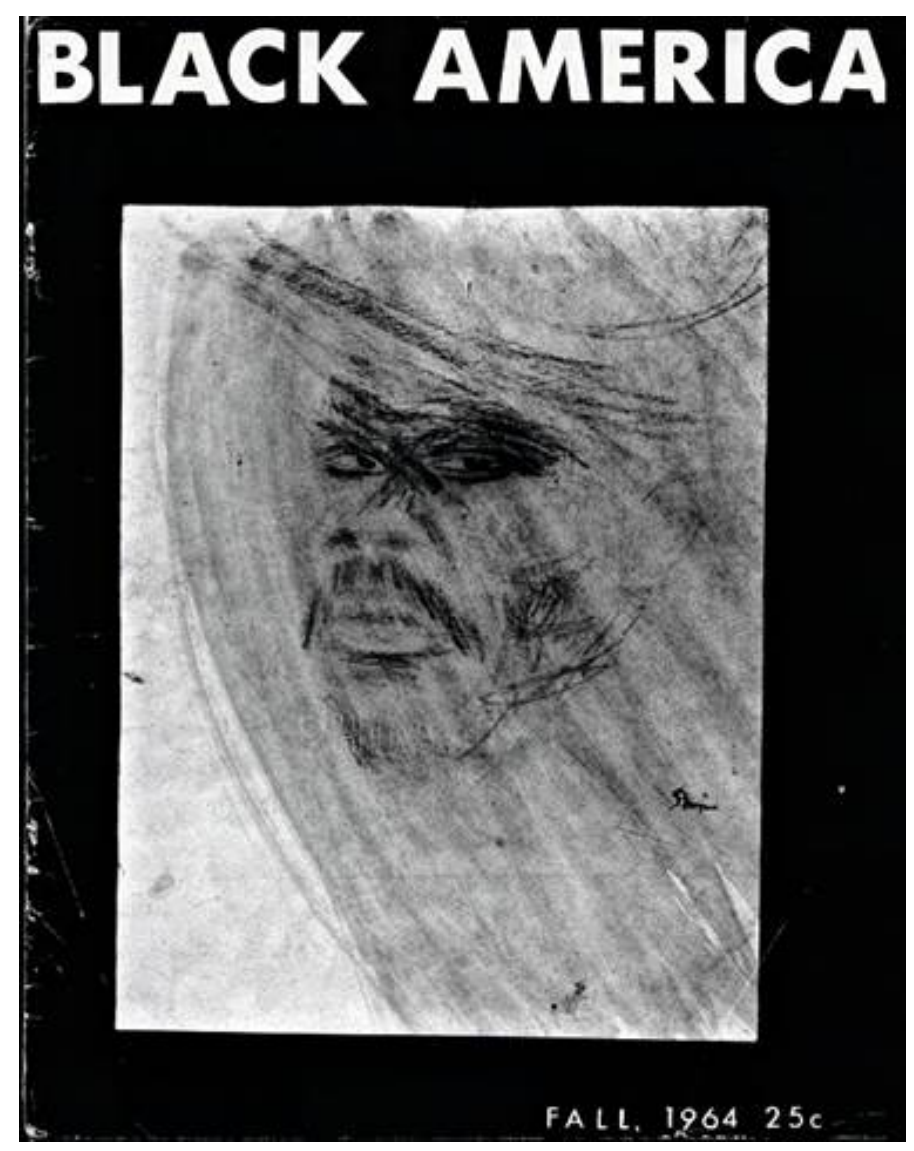

Figure 3 Cover of Black America, fall 1964. Max Stanford.

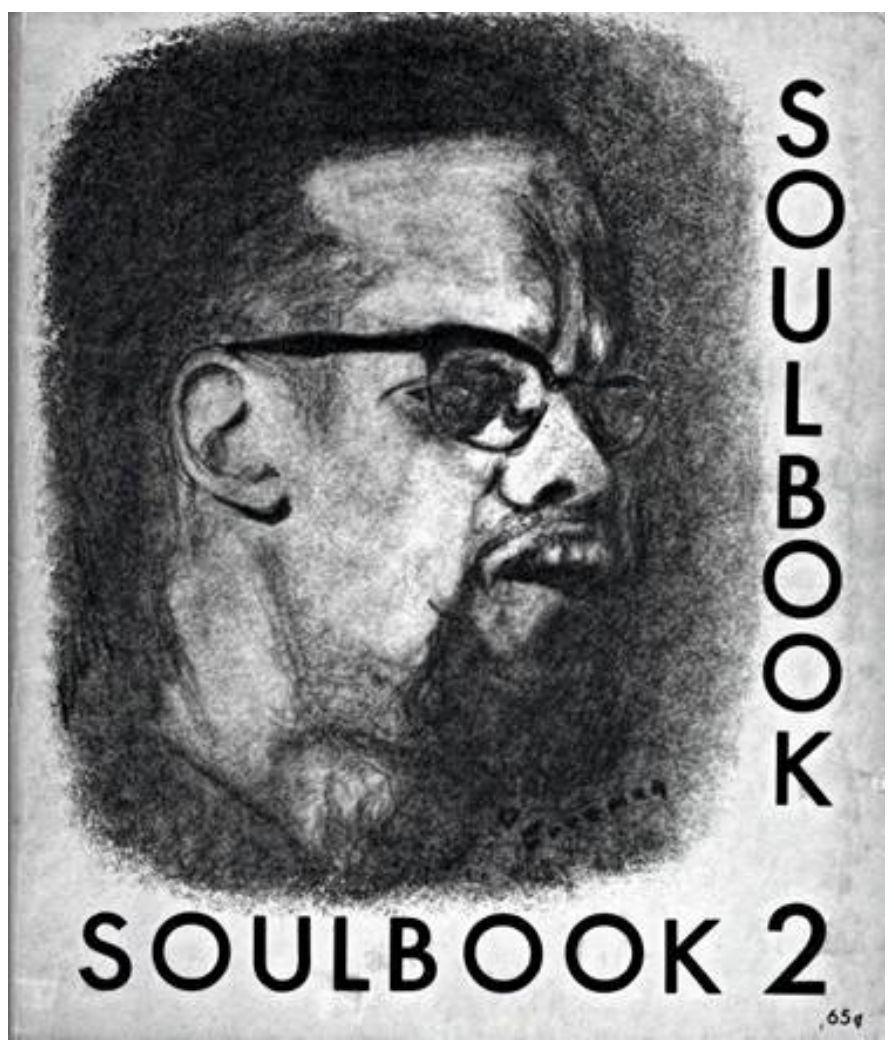

Figure 4 Cover of Soulbook, spring 1965. Donald Freeman. 
From a different perspective, Freeman's drawing for the spring 1965 issue of Soulbook demonstrated how the cover design of radical black periodicals could be used to advance specific narratives or ideas about movement activists and organisations. One notable aspect of Freeman's stylisation of Malcolm was his decision to include the minister's beard. While Malcolm would later contend that his decision to grow facial hair had 'no particular meaning, other than it probably reflects a change that I've undergone and am still undergoing', scholars such as Carol Tulloch have pointed to Malcolm's beard as an important physical marker of his spiritual and ideological transformation. ${ }^{52}$ If Malcolm's decision to grow, and keep, a beard on his pilgrimage to Mecca in 1964 helped to establish his status as a 'new man' freed from the ideological shackles of the Nation of Islam, Freeman's decision to depict Malcolm with his facial hair intact served to temporally frame Soulbook's commemoration of Malcolm after his split from the Nation and subsequent conversion to orthodox Islam. This sentiment was reinforced through Bobb Hamilton's eulogy, which addressed Malcolm as El Hajji Malik Shabazz and directed blame for his death towards Elijah Muhammad and the Nation.

If such artistic decisions could help to subtly orientate black radical publications, there were other important differences within the new wave of black radical magazines. During the first few years of the decade, the East Coast, and in particular New York, had reigned supreme as the guiding hub for black radical print. However, the publication of Soulbook out of Berkeley, California, helped to mark a shift away from the East Coast and a nationalisation of the production, as well as distribution, of black radical periodicals. This was a shift that would continue during the second half of the decade, as Tom Dent and other leading black radical artists and editors moved away from the Northeast to participate in new black arts projects such as the Free Southern Theater and BLKARTSOUTH. ${ }^{53}$ On the West Coast, the Bay Area became a fertile space for black nationalist and New Left activism, leading to the creation of new periodicals such as The Movement newspaper, supported by the Student Nonviolent Coordinating Committee and Students for a Democratic Society, which grew alongside radical literary and political magazines such as Ramparts.

\section{Emory Douglas, the Black Panther and the artist as revolutionary}

Perhaps, the most dynamic new periodical to emerge during the Black Power era was the Black Panther, the official publication of the Black Panther Party. The Panthers had been founded in October 1966 by Bobby Seale and Huey P. Newton, and the Black Panther began publication around half a year later. From the outset, it was a vital tool for recruiting new members, communicating Panther activities and raising money. ${ }^{54}$ At the peak of its readership in the late 1960s and early 1970s, scholars have estimated that the Panther's weekly circulation breached 100,000. ${ }^{55}$ This meant that it was not only the primary vehicle for recording and disseminating the Party's ideology and history, but also a major revenue stream. Former Panther David Hilliard recalls that sales of the newspaper supported 'maintenance of our offices and our school, the Oakland Community Learning Center, as well as our Free Breakfast for Children and other Survival Programs' ${ }^{56}$ When the paper faced sabotage through law enforcement over inking printing batches or intercepting newspapers at airport and bus terminals, the Party responded by distributing printer plates to local branches in an effort to decentralise production.

Early covers of the Black Panther were presented in a more conventional black-and-white newspaper layout, with an emphasis on headlines and story copy over images. As was the case with other black radical periodicals, financial challenges contributed to the Panther's monochromatic appearance. The first issue of the paper consisted of little more than two mimeographed sheets stuck together and, until the Party succeeded in establishing a more secure economic foothold, it was simply unable to provide the funds needed for higher production values ${ }^{57}$ In contrast to periodicals such as Umbra, which were dominated by black intellectuals and artists, much of the early production of the Black Panther was overseen by rank-and-file Party members, although this did not mean that all of its contributors were novices in the world of publishing. Eldridge Cleaver had gained journalistic experience writing for Ramparts, a glossy political and literary magazine published in San Francisco which had close links to the New Left, while Seale had briefly worked for Soulbook as the periodical's distribution manager. However, many of the newspaper's staff had little to no experience in publishing, lending early issues a decidedly amateur feel. 
A key figure behind the Panther's transformation from a low-quality 'community news service' into a visually striking and widely circulating weekly newspaper was Emory Douglas, the Party's Minister of Culture and in-house 'Revolutionary Artist'. In addition to producing a wide assortment of cover art for the Panther, Douglas created many of the paper's internal illustrations and orchestrated its general layout and design. Douglas had been brought into the Party fold whilst he was still enrolled as a commercial art student at San Francisco City College, and his experience in printing, graphic design and collage provided him with a strong platform for the development of his politically infused artwork. The artist recalls working alongside Cleaver out of the latter's studio apartment to produce early copies of the paper, armed only with exacto blades, rubber cement glue and repurposed white paper. ${ }^{58} \mathrm{~A}$ good early example of Douglas' influence over the paper can be seen on the cover of its third issue published on 20 June 1967, which featured one of the artist's heavily stylised images alongside a poem titled 'On Revolutionary Art'. Through combining graphic design with the written word, Douglas celebrated the importance of 'painting revolutionary things, painting beautiful things, too. Trying to brain wash the brainwashed with a stroke or two'. 59

As the Panthers' Minister of Culture, Douglas wholeheartedly endorsed the revolutionary potential of art as a tool in the black liberation struggle, imploring black artists to 'take up their paints and brushes in one hand and their gun in the other' ${ }^{60}$ Eschewing more abstract or ethereal forms of artwork and graphic design, Douglas' work was explicitly and unashamedly militant, featuring heavily stylised black guerrillas ready to wage war against both named and unnamed forces. As a form of artwork 'designed to rip the heart out of those oppressing the black community', his anthropomorphic depictions of corrupt police officers and politicians as pigs and rats were heavily criticised in some quarters for being racially antagonistic. In a 1970 report from the House Committee on Internal Security, Douglas' artwork was used as evidence that the Panthers were a domestic terror group intent on 'violent revolution' ${ }^{61}$ However, critics such as Nicolas Lampert have noted that behind its 'veneer of violence' lay an altogether more pragmatic veneration of Panther ideology. Through his graphic design and cover art, Douglas used the Panther to create a visual history of the Party's agenda, helping to develop a 'protest aesthetic' which fused the Panthers ideology to a distinct Black Power style. ${ }^{62}$

For many Party affiliates, Douglas' depictions of violence were less a call to arms against white America and more a visual response to and graphic rendering of the continuing patterns of state-sanctioned violence levied against African American communities. Just as early Panther projects such as armed patrols struck a delicate balance between self-defence and provocation, so too did Douglas' artwork constitute 'both a practical and symbolic challenge to the daily operation of police forces' in the Bay Area and in other black enclaves across the country. ${ }^{63}$ In addition to its more generalised function, Douglas' work underpinned specific campaigns, such as the effort to exonerate Huey Newton following his involvement in an October 1967 shooting that left Oakland police officer John Frey dead and Newton critically wounded and facing multiple felony charges. ${ }^{64}$ At the same time, the Panther began to shift away from the more traditional newspaper layout that had characterised many of its early issues. By the last quarter of 1968, its front page more closely resembled that of a political magazine than of a conventional newspaper, as seen through the use of full-page artwork or photographs of prominent Panther leaders. ${ }^{65}$ Coupled with an increasing production budget and an expanded colour palette, such changes helped to better showcase Douglas' work and provide new opportunities for the artist to visualise the Party's ideology.

One notable feature of Douglas' cover art was its celebration of black women as active participants in the black liberation struggle. This reflected the Panthers' relatively egalitarian position on gender and sexual equality, particularly in comparison to earlier publications such as Black America and the rhetoric of cultural nationalists who maintained that black women were unfit for leadership and 'should be restricted to supportive or subordinate roles' ${ }^{66}$ Rejecting the restrictive or selective vision of black womanhood presented in many of the earlier periodicals discussed in this essay, Douglas strove to portray the lived experiences of working-class black women 'with their hair in braids, with frayed sleeves and worn shoes', as well as gun-toting Black Power 'sisters' armed with machine guns, machetes and grenades. ${ }^{67}$ Such artwork reflected the centrality of women to the Party, from the rank-and-file to its leadership. By 1970, figures such as Newton were arguing that to achieve total liberation, the Panthers should unite 
with gay liberation and women's liberation 'in a revolutionary fashion' ${ }^{68}$ Douglas' artwork is therefore instructive in relaying this message and helping to push back against popular depictions of the Party as a deeply misogynistic organisation. That is not to say that the Panthers were immune to such concerns, with members such as Roberta Alexander speaking out about 'the problem of gender politics in the Party' ${ }^{69}$ However, the Panther's cover art and graphic design can be argued to have both emphasised and celebrated the role of black women in the struggle for black liberation.

Perhaps, the most important function of Douglas' cover art for the Black Panther was its role in helping readers to trace the Party's shifting activist priorities and ideological orientation during the years following its emergence on the national stage. As figures such as Newton came to embrace an increasingly diasporic understanding of the black freedom struggle, so too did Douglas' work explicitly connect police brutality in the United States to the ongoing war in Vietnam. The cover of the September 1969 issue of the Black Panther (Figure 5) captures many of the aesthetic features which made Douglas' work so compelling, including his use of bold lines and geometric patterns, heavily stylised portraiture and a mixing of different visual mediums. Perhaps more importantly, it exhibits his incisive understanding of the physical and psychological relationship between African American communities and the black diaspora, and his ability to translate the Party's core beliefs and values into a visual medium that carried mass appeal. Such powerful visual connections between domestic state violence and American imperial aggression abroad reflected the Party's belief that 'their struggle in the United States [was] not only necessary for the liberation of blacks and other oppressed people in America but [was] a struggle whose success was critical for the liberation of exploited nations worldwide' ${ }^{70}$

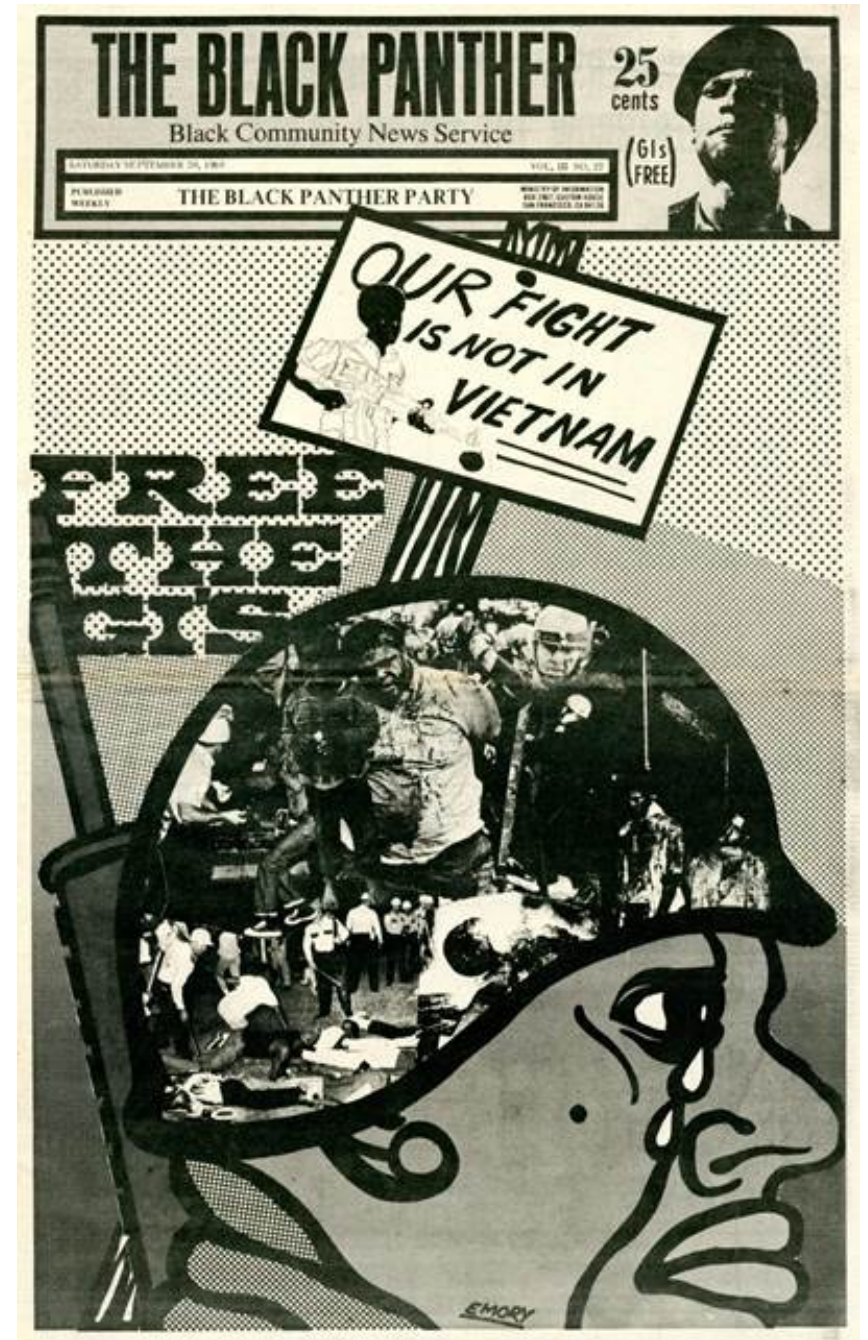

Figure 5 Cover of the Black Panther, 20 September 1969. (c) Emory Douglas/DACS 2017. 


\section{Conclusion}

The different periodicals examined in this essay were ideologically and editorially diverse, ranging from organisational instruments like the Black Panther and militant black nationalist outlets such as Black America to pioneering Pan-African journals such as the Liberator. Each of these publications was, in its own way, unique: the product of competing editorial and ideological visions, the specific artistic talents and technologies available to their editors, and the cultural and political contexts of the cities within which they were produced and disseminated. Nevertheless, as a collective, they were deeply engaged with Black Power philosophies and attuned to broader shifts in movement activism, something which manifested itself through their production and cover design. ${ }^{71}$ By moving away from a more traditional newspaper-style format to embrace formats which would show off their radical artwork, these periodicals demonstrated the extent to which cover design could be incorporated into a broader embrace of progressive or militant editorial politics. In the process, they contributed to the formation of a distinct 'Black Power aesthetic'.

It is certainly true that economic precarity was an enduring reality for many of these publications something which led to irregular printings, erratic production values and inconsistences in both editorial and artistic content. ${ }^{72}$ In the first anniversary issue of Liberator, its editors had jokingly attributed its survival to the journal being 'too poor to be sued' and 'too small to be attacked' ${ }^{73}$ However, as this comment suggests, the marginal status of these periodicals allowed them to produce more radical forms of illustration and graphic design and develop covers which would never have been published in outlets that were more dependent on advertising revenues. The reliance on amateur artists or in-house editors to produce cover artwork also pointed to the economic pressures which limited many of these outlets. Yet, this too carried a benefit, with the frequent overlap between artist and editor helping to synergise these different aspects of periodical content. However, this close relationship between cover art and content also had problematic consequences, such as reinforcing gendered ideas about Black Power, black nationalism and black liberation.

As radical ideas moved from the margins to the centre of the black liberation struggle and radical black print culture gained a more substantial footing, artists and outlets such as Emory Douglas and the Black Panther were able to develop increasingly sophisticated graphic designs to better reflect their own understanding of and engagement with Black Power. For Douglas, eye-catching cover art was not just a way of boosting the Party's revenue stream; it was an important method of articulating key ideological concerns, disseminating the Party's message and framing the mainstream media response to it. As recent projects, such as Sam Durant's 2014 collection Black Panther: The Revolutionary Art of Emory Douglas and exhibits, such as Soul of a Nation: Art in the Age of Black Power, demonstrate, Douglas' work has begun to receive the critical and popular acclaim it deserves. ${ }^{74}$ Yet, this appreciation of Douglas should not be viewed in isolation. As this essay has shown, the evolution and significance of Douglas' artwork for the Black Panther is just one example of Black Power's broader impact on black American graphic design and print culture during the 1960s and 1970s.

\section{Declarations and conflict of interests}

The author declares no conflicts of interest with this publication.

\section{Notes}

1 'Soul of A Nation,' Tate Modern, 12 July-22 October 2017, http://www.tate.org.uk/whats-on/tatemodern/exhibition/soul-nation-art-age-black-power.

2 This literary focus has been codified through scholarship such as James Smethurst's seminal text The Black Arts Movement: Literary Nationalism in the 1960s and 1970s (Chapel Hill: University of North Carolina Press, 2005).

${ }^{3}$ This is beginning to change, in large part due to the efforts of new organisations such as the African American Intellectual History Society and the Black Press Research Collective. Angelica McKinley and Giovanni Russonello, 'Fifty Years Later, Black Panthers Art Still Resonates,' New York Times, October 15, 2016. 
${ }^{4}$ Peniel E. Joseph, 'Black Power Studies: A New Scholarship,' The Black Scholar, 31 (2001), 1.

${ }^{5}$ Jeffrey Ogbar, Black Power: Radical Politics and African American Identity (Baltimore: Johns Hopkins University Press, 2004), 139. For a sample of recent literature see Martha Biondi, The Black Revolution on Campus (Berkeley: University of California Press, 2012); John Bracey, Sonia Sanchez and James Smethurst, eds., SOS/Calling All Black People: A Black Arts Movement Reader (Amherst: University of Massachusetts Press, 2014); Sean Malloy, Out of Oakland: Black Panther Party Internationalism during the Cold War (Ithaca: Cornell University Press, 2017); Kate Quinn, ed., Black Power in the Caribbean (Gainesville: University Press of Florida, 2015); Russell Rickford, We Are An African People: Independent Education, Black Power, and the Radical Imagination (Oxford: Oxford University Press, 2016); Nico Slate, ed., Black Power Beyond Borders: The Global Dimensions of the Black Power Movement (Basingstoke: Palgrave Macmillan, 2012); Rychetta Watkins, Black Power, Yellow Power and the Making of Revolutionary Identities (Jackson: University Press of Mississippi), 2014; Rhonda Williams, Concrete Demands: The Search For Black Power in the 20th Century (New York: Routledge, 2014).

${ }^{6}$ Joseph himself has been guilty of this trend, with his expansive biographical account of Stokely Carmichael's life serving to reify his position as the unofficial figurehead of the Black Power movement. Peniel Joseph, Stokely: A Life (New York: Civitas, 2014); Peter Ling, 'Does the Movement Need a King?' Journal of American Studies, 50 (2016), 465-70.

${ }^{7}$ A number of recent monographs have begun to address this issue in more detail. Tom Adam Davies, Mainstreaming Black Power (Berkeley: University of California Press, 2017); Kerry Pimblott, Faith in Black Power: Religion, Race and Resistance in Cairo, Illinois (Lexington: University of Kentucky Press, 2017); Christopher Tinson, Radical Intellect: Liberator Magazine and Black Activism in the 1960s (Chapel Hill: University of North Carolina Press, 2017).

${ }^{8}$ For an introduction into such debates, see Lara Cohen and Jordan Stein, eds., Early African American Print Culture (Pennsylvania: University of Pennsylvania Press, 2012); James Danky and Wayne Wiegand, eds., Print Culture in a Diverse America (Urbana: University of Illinois Press, 1998).

${ }_{9}^{9}$ William Jordan, Black Newspapers and America's War for Democracy, 1914-1920 (Chapel Hill: University of North Carolina Press, 2001); Ida B. Wells and Jacqueline Royster, Southern Horrors and Other Writings: The Anti-Lynching Campaign of Ida B. Wells, 1892-1900 (Boston: Macmillan, 2016); Bill Mullen, Popular Fronts: Chicago and African American Cultural Politics, 1935-1946 (Urbana: University of Illinois Press, 1999); Lindsey Swindall, Paul Robeson: A Life of Activism and Art (Lanham: Rowman \& Littlefield, 2015).

${ }^{10}$ Colin Grant, Negro With A Hat: The Rise and Fall of Marcus Garvey (Oxford: Oxford University Press, 2008), 136; Theodore Kornweibel, Seeing Red: Federal Campaigns against Black Militancy, 1919-1925 (Bloomington: Indiana University Press, 1998), 91; Shelley Streeby, Radical Sensations: World Movements, Violence, and Visual Culture (Durham: Duke University Press, 2013), 14.

${ }^{11}$ Abby Arthur Johnson and Ronald Maberry Johnson, Propaganda and Aesthetics: The Literary Politics of African-American Magazines in the Twentieth Century (Amherst: University of Massachusetts Press, 1991), 161.

12 Clare Corbould, Becoming African Americans (Cambridge: Harvard University Press, 2009); Eric Gardner, Black Print Unbound: The Christian Recorder, African American Literature and Periodical Culture (Oxford: Oxford University Press, 2015); Gerald Horne, The Rise and Fall of the Associated Negro Press (Urbana: University of Illinois Press, 2017); Lara Putnam, Radical Moves: Caribbean Migrants and the Politics of Race in the Jazz Age (Chapel Hill: University of North Carolina Press, 2013).

${ }^{13}$ Corbould, Becoming African Americans, 52; Amy Kirschke, Aaron Douglas: Art, Race, and the Harlem Renaissance (Jackson: University Press of Mississippi, 1995), 68-9.

14 Johnson and Johnson, Propaganda and Aesthetics, 161; Rychetta Watkins, Black Power, Yellow Power, and the Making of Revolutionary Identities (Jackson: University Press of Mississippi, 2012), 122.

15 Andrew Anthony, 'Black Power's Coolest Radicals,' The Guardian, October 18, 2010; Stokely Carmichael and Charles V. Hamilton, Black Power: The Politics of Liberation in America (New York: Vintage Books, 1967); 'Cover', Ebony, August 1969; 'Cover', Ebony, August 1972. 
${ }^{16}$ For more on Black Power era book cover design, see Josh MacPhee's excellent 2016 essay in Print; MacPhee, 'Power, Fists, Guns, Books: Black Power \& Book Cover Design,' Print, June 13, 2016; Alexis Pauline Gumbs, 'Black (Buying Power): The Story of Essence Magazine,' in The Business of Black Power: Community Development, Capitalism, and Corporate Responsibility in Postwar America, ed. Lauren Hill and Julia Rabig (Rochester: University of Rochester Press, 2012), 95.

17 Tinson, Radical Intellect, 9; Jane Rhodes, 'The Black Press and Radical Print Culture,' in A History of the Book in America: Volume 5, ed. David Nord et al., (Chapel Hill: University of North Carolina Press, 2009), 287.

18 'Cover', Liberation Newsletter, March 1961.

${ }^{19}$ Jerry Gafio Watts, ed., Harold Cruse's The Crisis of the Negro Intellectual Reconsidered (New York: Routledge, 2004), 31-3; 'LCA First Anniversary Meeting a Tremendous Success,' Liberator, June 1961, 1. ${ }^{20}$ Tinson, Radical Intellect, 1.

21 'Summary of LCA Finances,' Liberator, June 1961, 2.

${ }^{22}$ Linda Riggins, 'Black Pilgrimage,' Black World, November 1972, 92.

23 'Cover,' Liberator, May 1962, 2.

24 'Backstage,' Ebony, November 1945, 2; Peniel Joseph, 'Black Studies, Student Activism, and the Black Power Movement,' in The Black Power Movement, 257.

25 'Cover,' Liberator, October 1962.

26 'Liberator,' Liberator, November-December 1962, 2.

27 'Natural Hair YES, Hot Irons NO', Liberator, July 1963, 12-3.

28 'Skintona,' Ebony, June 1961, 12; Susannah Walker, Style and Status: Selling Beauty to African American Women, 1920-1975 (Lexington: University Press of Kentucky).

29 'Natural Hair Yes, Hot Irons No,' Liberator, July 1963, 13.

${ }^{30}$ Tanisha Ford, Liberated Threads: Black Women, Style, and the Global Politics of Soul (Chapel Hill: University of North Carolina Press, 2015), 41.

${ }^{31}$ James Smethurst, 'Poetry and Sympathy: New York, the Left, and the Rise of Black Arts,' in Left of the Color Line: Race, Radicalism and Twentieth Century Literature of the United States, ed. Bill Mullen and James Smethurst (Chapel Hill: University of North Carolina, 2003), 265.

32 Calvin Hernton, 'Umbra: A Personal Recounting,' African American Review, 27 (1993), 579.

${ }^{33}$ Johnson and Johnson, Propaganda and Aesthetics, 163.

34 'Umbra Writer's Workshop,' Box 97, Tom Dent Papers, Tulane University.

35 Aldon Lynn Nielsen, Black Chant: Languages of African American Postmodernism (Cambridge: Cambridge University Press, 1997), 111.

36 Jean-Philippe Marcoux, Jazz Griots: Music as History in the 1960s African American Poem, 71.

${ }^{37}$ Hernton, 'Umbra,' 580.

${ }^{38}$ Smethurst, The Black Arts Movement, 128; Joshua Bloom and Waldo E. Martin, Jr., Black Against Empire: The History and Politics of the Black Panther Party (Oakland: University of California Press, 2013), 31.

${ }^{39}$ Ahmed extensively outlines RAMs philosophy in his Masters' dissertation. 'Revolutionary Action Movement (RAM): A Case Study of an Urban Revolutionary Movement in Western Capitalist Society' (Master's diss.: Atlanta University, 1986); Ahmad, 'History of RAM - Revolutionary Action Movement,' Freedom Archives, accessed April 15, 2018. http://freedomarchives.org/.

${ }^{40}$ Ahmed, 'Revolutionary Action Movement,' 92.

${ }^{41}$ Ogbar, Black Power 78.

42 'Purpose,' Black America, Summer-Fall 1965, 2.

${ }^{43}$ Rolland Murray, Our Living Manhood: Literature, Black Power, and Masculine Ideology (Philadelphia: University of Philadelphia Press, 2015), 55.

${ }^{44}$ Dean Robinson, Black Nationalism in American Politics and Thought (Amherst: University of Massachusetts Press, 2001), 60.

45 'Contents,' Black America, Fall 1964, 2.

${ }^{46}$ Watts, ed., Harold Cruse's The Crisis of the Negro Intellectual Reconsidered, 31-2. 
47 'To The Peoples of Afroamerica,' Soulbook, 1 (Winter 1964), 3.

${ }^{48}$ Anna Pochmara, The Making of the New Negro: Black Authorship, Masculinity, and Sexuality in the Harlem Renaissance (Amsterdam: Amsterdam University Press, 2011), p. 10.

${ }^{49}$ Ashley Farmer, Remaking Black Power: How Black Women Transformed an Era (Chapel Hill: University of North Carolina Press, 2017).

50 Jerry Watts, Amiri Baraka: The Politics and Art of a Black Intellectual (New York: New York University Press, 2001), 219.

${ }^{51}$ Bobb Hamilton, 'El Hajji Malik Shabazz: Leader, Prophet, Martyr', Soulbook, 4 (1965), 81.

${ }^{52}$ Carol Tulloch, The Birth of Cool: Style Narratives of the African Diaspora (London: Bloomsbury Academic, 2016), 144.

${ }^{53}$ Rickford, We Are An African People, 147.

${ }^{54}$ Joshua Bloom and Waldo Martin, Black Against Empire: The History and Politics of the Black Panther Party (Berkeley: University of California Press, 2013), 79.

55 James Philip Jeter et al., International Afro Mass Media: A Reference Guide (Westport: Greenwood Press, 1996), 233; Charles E. Jones and Judson L. Jeffries, 'Don't Believe the Hype: Debunking the Panther Mythology,' in The Black Panther Party (Reconsidered), ed. Charles Earl Jones, (Baltimore: Black Classic Press, 1998), 29.

${ }^{56}$ David Hilliard, 'Preface', in The Black Panther, ed. Hilliard (New York: Atria Books, 2007), 8.

${ }^{57}$ Bloom and Martin, Blacks Against Empire, 56.

58 'Emory Douglas: The Art of the Black Panthers,' Dir. Andre Andreev and Dan Covert, Dress Code, accessed May 20, 2018. https://dresscodeny.com/work/emory-douglas-art-of-the-black-panthers/.

${ }^{59}$ Douglas, 'On Revolutionary Art,' Black Panther, 20 June 1967, 1.

${ }^{60}$ Erika Doss, 'Revolutionary Art is a Tool for Liberation: Emory Douglas and Protest Aesthetics at the Black Panther,' in Liberation, Imagination and the Black Panther Party, ed. Kathleen Cleaver and George Katsiaficas (London: Routledge, 2001), 175.

${ }^{61}$ U.S Congress House Committee on Internal Security, 'Hearings before the Committee on Internal Security, Second Session' (Washington D.C.: U.S Government Printing Office, 1970), 170.

${ }^{62}$ Nicolas Lampert, A People's Art History of the United States (New York: The New Press, 2013), 199-200.

${ }^{63}$ Nicolas Lampert, A People's Art History of the United States (New York: The New Press, 2013), 199-200.

${ }^{64}$ Doss, 'Revolutionary Art is a Tool for Liberation,' 176.

${ }^{65}$ Black Panther, 19 October 1968; Black Panther, 7 December 1968.

${ }^{66}$ Christopher Brian Booker, I Will Wear No Chain: A Social History of African American Males (Westport: Praeger, 2000), 195.

${ }^{67}$ Black Panther, 12 July 1969, 1.

${ }^{68}$ Huey Newton, Huey P. Newton: The Radical Theorist, quoted Jeffries (Jackson: University Press of Mississippi, 2002), 28.

${ }^{69}$ Bloom and Martin, Black Against Empire, 303.

70 Jeffries, Huey P. Newton: The Radical Theorist, 74.

${ }^{71}$ Carolyn Gerald, 'The Measure and Meaning of the Sixties,' Negro Digest, November 1969, 24.

72 Johnson and Johnson, Propaganda and Aesthetics, 164.

73 'After One Year,' Liberator, May 1962, 2.

${ }^{74}$ Sam Durant, 'Introduction,' in Black Panther: The Revolutionary Art of Emory Douglas, ed. Sam Durant (New York: Rizzoli, 2014), 19.

\section{References}

Periodicals

Black America

Black Panther

Chicago Defender 
The Crisis

Ebony

Essence

Freedom

The Guardian

Liberator

The Messenger

Negro Digest/Black World

Negro World

New York Times

Opportunity

Ramparts

Soulbook

Umbra

\section{Other Sources}

Ahmad, Muhammad [Max Stanford]. 'Revolutionary Action Movement (RAM): A Case Study of an Urban Revolutionary Movement in Western Capitalist Society'. Thesis, Atlanta University, 1986.

Biondi, Martha. The Black Revolution on Campus. Berkeley: University of California Press, 2012.

Bloom, Joshua, and Waldo E. Martin, Jr. Black against Empire: The History and Politics of the Black Panther Party. Oakland: University of California Press, 2013.

Booker, Christopher Brian. I Will Wear No Chain: A Social History of African American Males. Westport: Praeger, 2000.

Bracey, John, Sonia Sanchez, and James Smethurst, eds. SOS/Calling All Black People: A Black Arts Movement Reader. Amherst: University of Massachusetts Press, 2014.

Carmichael, Stokely, and Charles V. Hamilton. Black Power: The Politics of Liberation in America. New York: Vintage Books, 1967.

Corbould, Clare. Becoming African Americans. Cambridge: Harvard University Press, 2009.

Cohen, Lara, and Jordan Stein, eds. Early African American Print Culture. Pennsylvania: University of Pennsylvania Press, 2012.

Danky, James, and Wayne Wiegand, eds. Print Culture in a Diverse America. Urbana: University of Illinois Press, 1998.

Davies, Tom Adam. Mainstreaming Black Power. Berkeley: University of California Press, 2017.

Doss, Erika. 'Revolutionary Art Is a Tool for Liberation: Emory Douglas and Protest Aesthetics at the Black Panther'. In Liberation, Imagination and the Black Panther Party, edited by Kathleen Cleaver and George Katsiaficas, 175-87. London: Routledge, 2001.

Durant, Sam, ed. Black Panther: The Revolutionary Art of Emory Douglas. New York: Rizzoli, 2014.

Ford, Tanisha. Liberated Threads: Black Women, Style, and the Global Politics of Soul. Chapel Hill: University of North Carolina Press, 2015.

Gardner, Eric. Black Print Unbound: The Christian Recorder, African American Literature and Periodical Culture. Oxford: Oxford University Press, 2015.

Grant, Colin. Negro with A Hat: The Rise and Fall of Marcus Garvey. Oxford: Oxford University Press, 2008.

Gumbs, Alexis Pauline. 'Black (Buying Power): The Story of Essence Magazine'. In The Business of Black Power: Community Development, Capitalism, and Corporate Responsibility in Postwar America, edited by Lauren Hill and Julia Rabig, 95-115. Rochester: University of Rochester Press, 2012.

Hernton, Calvin. 'Umbra: A Personal Recounting'. African American Review 27 (1993): 579-84.

Hilliard, David, ed. The Black Panther. New York: Atria Books, 2007.

Horne, Gerald. The Rise and Fall of the Associated Negro Press. Urbana: University of Illinois Press, 2017.

Johnson, Abby Arthur, and Ronald Maberry Johnson. Propaganda and Aesthetics: The Literary Politics of African-American Magazines in the Twentieth Century. Amherst: University of Massachusetts Press, 1991. 
Jordan, William. Black Newspapers and America's War for Democracy, 1914-1920. Chapel Hill: University of North Carolina Press, 2001.

Joseph, Peniel E. 'Black Power Studies: A New Scholarship'. The Black Scholar 31 (2001): 1.

Stokely: A Life. New York: Civitas, 2014.

Kirschke, Amy. Aaron Douglas: Art, Race, and the Harlem Renaissance. Jackson: University Press of Mississippi, 1995.

Kornweibel, Theodore. Seeing Red: Federal Campaigns Against Black Militancy, 1919-1925. Bloomington: Indiana University Press, 1998.

Ling, Peter. 'Does the Movement Need a King?'. Journal of American Studies 50 (2016): 465-70.

MacPhee, Josh. 'Power, Fists, Guns, Books: Black Power \& Book Cover Design'. Print, 13 June 2016.

Malloy, Sean. Out of Oakland: Black Panther Party Internationalism during the Cold War. Ithaca: Cornell University Press, 2017.

Marcoux, Jean-Philippe. Jazz Griots: Music as History in the 1960s African American Poem. Durham: Duke University Press, 2012.

Mullen, Bill. Popular Fronts: Chicago and African American Cultural Politics, 1935-1946. Urbana: University of Illinois Press, 1999.

Murray, Rolland. Our Living Manhood: Literature, Black Power, and Masculine Ideology. Philadelphia: University of Philadelphia Press, 2015.

Nielsen, Aldon Lynn. Black Chant: Languages of African American Postmodernism. Cambridge: Cambridge University Press, 1997.

Ogbar, Jeffrey. Black Power: Radical Politics and African American Identity. Baltimore: Johns Hopkins University Press, 2004.

Pimblott, Kerry. Faith in Black Power: Religion, Race and Resistance in Cairo, Illinois. Lexington: University of Kentucky Press, 2017.

Pochmara, Anna. The Making of the New Negro: Black Authorship, Masculinity, and Sexuality in the Harlem Renaissance. Amsterdam: Amsterdam University Press, 2011.

Putnam, Lara. Radical Moves: Caribbean Migrants and the Politics of Race in the Jazz Age. Chapel Hill: University of North Carolina Press, 2013.

Quinn, Kate, ed. Black Power in the Caribbean. Gainesville: University Press of Florida, 2015.

Rhodes, Jane. 'The Black Press and Radical Print Culture'. In A History of the Book in America: Volume 5, edited by David Nord et al., 286-303. Chapel Hill: University of North Carolina Press, 2009.

Rickford, Russell. We Are An African People: Independent Education, Black Power, and the Radical Imagination. Oxford: Oxford University Press, 2016.

Robinson, Dean. Black Nationalism in American Politics and Thought. Amherst: University of Massachusetts Press, 2001.

Smethurst, James. The Black Arts Movement: Literary Nationalism in the 1960s and 1970s. Chapel Hill: University of North Carolina Press, 2005.

Smethurst, James. 'Poetry and Sympathy: New York, the Left, and the Rise of Black Arts'. In Left of the Color Line: Race, Radicalism and Twentieth Century Literature of the United States, edited by Bill Mullen and James Smethurst. Chapel Hill: University of North Carolina, 2003.

Slate, Nico, ed. Black Power beyond Borders: The Global Dimensions of the Black Power Movement. Basingstoke: Palgrave Macmillan, 2012.

Streeby, Shelley. Radical Sensations: World Movements, Violence, and Visual Culture. Durham: Duke University Press, 2013.

Swindall, Lindsey. Paul Robeson: A Life of Activism and Art. Lanham: Rowman \& Littlefield, 2015.

Tinson, Christopher. Radical Intellect: Liberator Magazine and Black Activism in the 1960s. Chapel Hill: University of North Carolina Press, 2017.

Tulloch, Carol. The Birth of Cool: Style Narratives of the African Diaspora. London: Bloomsbury Academic, 2016.

Van Deburg, William. New Day in Babylon: The Black Power Movement and American Culture, 1965-1975. Chicago: University of Chicago Press, 1992. 
Watkins, Rychetta. Black Power, Yellow Power and the Making of Revolutionary Identities. Jackson: University Press of Mississippi, 2014.

Watts, Jerry Gafio, ed. Harold Cruse's the Crisis of the Negro Intellectual Reconsidered. New York: Routledge, 2004.

Watts, Jerry. Amiri Baraka: The Politics and Art of a Black Intellectual. New York: New York University Press, 2001.

Williams, Rhonda. Concrete Demands: The Search for Black Power in the 20th Century. New York: Routledge, 2014. 